\title{
Computerspil og læring
}

- en undersøgelse af, hvordan

læring foregår i computerspillet

StarCraft 2

\section{Lasse Juel Larsen}

Ph.D, Mag.Art.

Medievidenskab på Syddansk Universitet

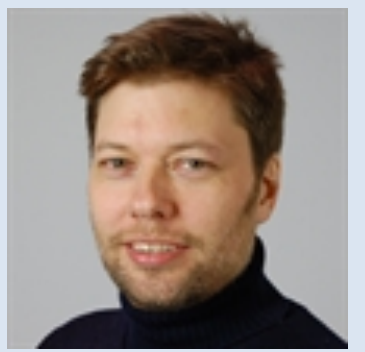




\section{Abstract}

Denne artikel vil analytisk undersøge, hvordan computerspil og læring går i forbindelse med hinanden. Artikel tager afsæt i Gregory Batesons læringsteori og læser denne igennem det kommercielle computerspil StarCraft 2 (Blizzard Entertainment, 2010). Batesons læringsteori vil ikke alene blive gennemgået, men også udvidet og perspektiveret. Formålet med denne indsats er at skabe et afsæt, der kan demonstrere, hvordan læring foregår i StarCraft 2. Herefter vil afsættet blive anvendt til at destillere et læringsteoretisk udkast. Artiklen falder således i to dele, hvor den første analytisk adresserer, hvordan læring foregår i StarCraft 2, mens den anden er teoriproducerende på baggrund af resultaterne fra første del.

Nøgleord: computerspil, læring, teori, ekspansion, identitet, forskel, selvreferents, StarCraft 2, Bateson.

\section{Indledning}

Når computerspil og læring bliver anvendt i samme sætning, så sker det ofte ud fra en af tre forskellige vægtninger af relationen mellem dem. Den første vægtning er optaget af, hvordan computerspil kan bruges som middel til at skabe læring hvad enten denne skal foregå i vuggestuen, børnehaven, skolen eller på universitetet. Denne tilgang bliver ofte kaldt spilbaseret læring (game-based learning) og går under betegnelsen Serious Games (Yee 2014).

Indenfor Serious Games samler interessen sig om, hvordan computerspil kan hjælpe læring af et bestemt indhold på vej. Dette kendetegnet ved en relation mellem computerspil og læring, hvor computerspil fungerer som medie for et på forhånd beskrevet og fastlagt læringsindhold. Her tjener computerspil et formål ud over sig selv. Den anden vægtning er interesseret i at finde ud af, hvad man lærer, når man spiller computerspil. Her samler interessen sig om, hvordan computerspil kan øge evnen til at overskue, bearbejde og løse komplekse opgaver. Denne vægtning er optaget af, hvilke kompetencer spilleren opnår ved at spille computerspil.

Hvis man anlægger et blik fra videnssystematikken på disse to vægtninger, så kredser den første vægtning om, hvordan spilleren lærer et 
ekspliceret (faktuelt) vidensindhold, mens den anden kredser om, hvordan læring af et læringsindhold foregår (processuel) (Gleerup 2011, Qvortrup 2005). Denne distinktion kan man genfinde hos David Williamson Shaffer, når han i How Computer Games Help Children Learn (2006) beskriver forskellen mellem

"knowing that and knowing how - between declarative knowledge and procedural knowledge, or being able to explain something and being able to actually do it - is fundamental to education as we know it."

(Shaffer 2006:91-92)

Selvsamme distinktion går igen, når Keith Devlin i Mathematics Education for a New Era - Video Games as a Medium for Learning (2011) forklarer forskellen mellem at løse regneopgaver og tænke matematik. Devlin skriver:

\footnotetext{
"whenever I tell someone that I am studying mathematics education (mat ed) video games, if they say anything at all, it is to ask me if I have seen or played game $\mathrm{X}$ and what do I think of it. Often I have, and I have to tell them that game X isn't really teaching or helping students learn mathematical thinking; rather, it is focused on trying to develop mastery of basic skills."
}

(Devlin 2011:3)

Devlins sondring mellem "basic skills" og "thinking" er parallel med William Shaffers opdeling i "declarative" og "procedural knowledge". I Persuasive Games - The Expressive Power of Videogames (2007) skriver Ian Bogost om disse to perspektiver:

\footnotetext{
"At the risk of oversimplification, most contemporary understandings of (formal) education fall largely in either the behaviorist or the constructionist theory of education. The "traditional" classroom relies on behaviorist learning strategies. Students practice within question/answer frames that reinforce knowledge of a subject matter. Students respond (in speech or writing, for example) and receive immediate feedback in the form of positive and negative reinforcement."
} 
(Bogost 2007:235)

Hvorimod det konstruktivistiske perspektiv understreger læring af

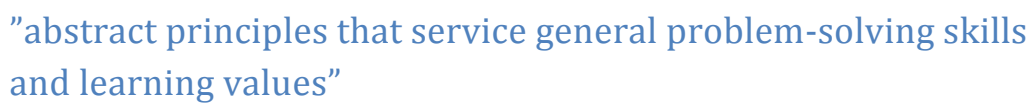

(Bogost 2007:239)

Denne opdeling er, som Bogost selv gør opmærksom på, forsimplet. På trods af denne skematiske generalisering, så er de to betragtninger indlejret i diskussionen om relationerne mellem computerspil og læring. Bogost foreslår en mulig vej mellem den abstraktionsfattige behaviorisme og indholdssvage konstruktivisme. Denne kalder han procedural literacy ud fra en forståelse af computerspil, der mener, at

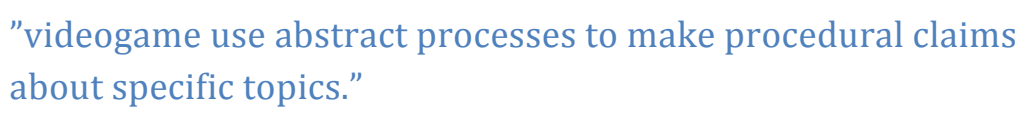

Her sigter Bogost efter læring, hvor abstrakte processer skaber konkrete erfaringer. Eller hvis rækkefølgen bliver vendt om: hvordan computerspil gennem partikulære sekvenser (indhold) kan lære et generelt og abstrakt indhold. Bogost interesserer sig således for "kommunikationen" mellem abstrakte processer og konkrete erfaringer. Vel at mærke stadig med fokus på læring af et indhold udenfor computerspillet selv.

Den tredje vægtning af relationen mellem computerspil og læring er i modsætning til de to foregående interesseret i, hvordan læring foregår inde i spillet. Den handler derfor om, hvordan spilleren lærer at spille computerspillet. Denne vægtning er inspireret af James Paul Gee, der i indledningen til What Video Games Have to Teach Us about Learning and Literacy $(2003,2005)$ forklarer, at computerspil først og fremmest lærer spillere at spille computerspil. De bliver bekendte med spillets indhold og den måde, hvorpå spillet er organiseret. Gennem forståelse af denne organisering får spilleren indsigt i spillet. 
Denne artikel er interesseret i den tredje vægtning af relationen mellem computerspil og læring. Til undersøgelsen af denne vil Gregory Batesons læringsteori, sådan som den optræder i Mentale Systemers Økologi (2005), vise sig at være et frugtbart udgangspunkt.

Artiklen indeholder således en undersøgelse af, hvordan læring foregår i StarCraft 2 og en gennemgang og udvidelse af Batesons læringsteori med henblik på at bane vejen for et udkast til en ekspansiv læringsteori.

Artiklen er med andre ord båret frem af en dobbelt ambition, hvor den første er en undersøgelse af, hvordan læring foregår i StarCraft 2, mens den anden anvender resultatet til at fremsætte et udkast til en ekspansiv læringsteori.

Det teoretiske udkast vil på en gang tage hensyn til læringens temporale såvel som spatiale dimensionalitet. Temporaliteten vedrører hvordan læring på en og samme tid foregå fremad- såvel som bagudrettet, mens spatialiteten handler om læringens krydsninger mellem vertikale og horisontale niveauer eller rettere, hvordan enkelte dele forbinder sig til hinanden med stigende kompleksitet i en ekspansiv matrice.

Artikel falder herfor i to dele: Den første analyserer, hvordan læring foregår i StarCraft 2, mens den anden anvender analysen til at fremsætte et udkast til en ekspansiv læringsteori.

\section{Fem aspekter af grundlaget for Batesons læringsteori}

Bateson baserer sin læringsteori på fem forbundne aspekter. Det første aspekt adresserer læring som et kommunikationsfænomen. Computerspil og kommunikation er tæt forbundne, da computerspil handler om kommunikation (Fullerton, 2008). Kort sagt: hvis ikke spillet bliver kommunikeret, så kan spilleren ikke finde ud af, hvad han/hun skal i spillet (Salen/Zimmerman, 2004). Det andet aspekt handler om interaktion. I Batesons læringsteori udgør interaktion et centralt omdrejningspunkt. Interaktion drejer sig om tilbagekoblinger (feed-back) (Goetz, 2011, Perry, 2013) i og mellem systemer, herunder mellem menneske og system.

Det tredje aspekt kredser om Bertram Russels typeteori. Det er en logisk opstilling, som hævder, 


\begin{abstract}
"at ingen klasse i en formel logisk eller matematisk diskurs kan være medlem af sig selv; at en klasse af klasser ikke kan være en af disse klasser, der udgør dens medlemmer."
\end{abstract}

(Bateson 2005:282)

Og videre,
"hvis vi klassificerer stole til at udgøre klassen af stole, kan vi ikke derefter notere, at borde og lampeskærme er medlemmer af en stor klasse af „ikke-stole”, men vi begår en fejl i formel diskurs, hvis vi regner klassen af stole med til elementerne i klassen af ikke-stole. For så vidt som ingen klasse kan være medlem af sig selv, kan klassen af ikke-stole tydeligvis ikke være en ikke-stol."

(Bateson 2005:283)

Bateson understreger, at Russels logiske typeteori er forskellige fra fænomenernes verden. Særligt vedrørende tid. Logiske systemer er uafhængige af og indeholder ingen tidslighed, mens fænomenernes verden hviler på tidslighed. Herved demonstrerer Bateson følsomhed ikke kun overfor fænomenernes verden, men også overfor sammenstillingen mellem logiske systemer og fænomenernes verden.

Ved hjælp af Russels typeteori opstiller Bateson fire forskellige læringskategorier. Disse skal, og dette er væsentligt, ikke forstås valoriseret sådan at læringskategori 0 (nullæring) er dårligere end læringskategori 3 (læring 3). Kategorierne er som sagt logiske og kun forbindes med hinanden, hvis en kategori enten tilhører en overgribende eller en underliggende kategori. Tilsammen udgør læringskategorierne 0, 1, 2, og 3 Batesons læringsteori.

Det fjerde aspekt handler om forandring som betingelse for læring. Bateson skriver,

\footnotetext{
"Ordet „læring” betegner uden tvivl forandring af en eller anden slags. Hvilken slags forandring er svært at sige."
}

(Bateson 2005:285) 
Batesons forståelse af forandring har afsæt i Newtons mekanik. Dermed er forandring knyttet til bevægelse. Bateson forklarer det sådan,

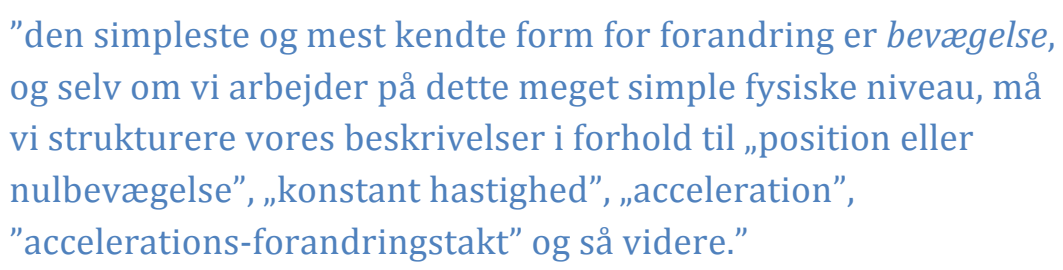

(Bateson 2005:285)

Det sidste og femte aspekt er koncentreret om at forbinde bevægelse med forandring gennem distinktionsmarkører for inddeling af læringskategorierne.

Disse fem aspekter udgør baggrundsmaterialet for Batesons læringsteori. De er videre tæt forbundne med StarCraft 2, der ligesom Batesons læringsteori hviler på kommunikation, interaktion, logiske typer, forandring og bevægelse. De parallelle træk mellem Batesons læringsteori og StarCraft 2 udgør en begrundelse for at anvende Batesons læringsteori i forbindelse med StarCraft 2.

\section{Nullæring - den første logiske kategori i Batesons læringsteori}

Forskydninger mellem læringskategorierne udgår som sagt fra forandring. Dette rejser spørgsmålet om, hvordan forandring indfinder sig. Ifølge Bateson udspringer forandring fra fejl og forsøg på korrektion af disse fejl. Følgende bliver fejl og forsøg på korrektion af fejl klassificerende for de forskellige læringskategorier. Hver læringskategori indeholder forskellige slags fejl og forskellige forsøg på korrektion af disse fejl.

Bateson forklarer,

\footnotetext{
"hvis vi nu accepterer den generelle opfattelse, at al læring (bortset fra nullæring) til en vis grad er stokastisk (dvs. rummer elementer af "forsøg og fejl”), følger det heraf, at en ordning af læreprocesserne kan bygges på en hierarkisk klassifikation af de typer af fejl, der skal rettes i de forskellige læreprocesser."
}

(Bateson 2005:288) 
Og nullæring er kendetegnet ved

"minimal forandring i sin reaktion på et gentaget sensorisk
inputelement."

(Bateson 2005:285)

Når citaterne sammenstilles kan nullæring betragtes både som en læringssituation, hvor der ikke optræder korrektion af fejl og som resultat og gentagelse af allerede etablerede og korrekte korrektioner på fejl.

Dette betyder, at nullæringskategorien er dobbelttydigt. På den ene side refererer nullæring til nutiden, hvor der i fremadrettede forløb ikke indtræder forsøg på fejlkorrektion og følgende ikke optræder forandring og derfor ingen læring. På den anden side refererer nullæring til gentagelse af allerede etablerede resultater af vellykkede fejlkorrektioner. Sådan at det fortsatte fremadrettede forløb bliver opretholdt af gentagelser uden forandring. Nullæringens dobbelttydighed kan illustreres ved hjælp af StarCraft 2.

\section{StarCraft 2 og nullæring}

StarCraft 2 tager som så mange andre real-time strategispil udgangspunkt $\mathrm{i}$, at spilleren skal opbygge en base, og at denne efterfølgende danner rammen om forsvar og/eller angreb på modstanderen alt afhængig af den pågældende missionsbeskrivelse. Det centrale i denne sammenhæng er, at spilleren for overhovedet at kunne udføre missionerne først skal forstå spillets basale konstruktions- og ressourcesystem. Centrum for dette er basens hovedbygning, Command Centeret. Spillet kræver derfor at spilleren kan identificere Command Centeret. Og herefter at spilleren forstår Command Centerets centrale position gennem det forhold, at det kun er den, der kan producere SCV-enheden (Space Construction Vehicle), som er afgørende for spillets progression.

SCV-enheden har en dobbelt funktion: 1) den samler ressourcer i form af mineraler eller vespene gas, 2) og den gør det muligt for spilleren at bygge og reparerer alle ikke-biologiske enheder og bygninger. Uden et Command 
Center og en SCV-enhed ingen base og følgelig ingen spiludvikling, forandring eller læring om man vil.

Spilleren skal altså identificere, hvordan et Command Center ser ud og lære hvilken funktion det har, samt forbinde SCV-enheden med Command Centeret og forstå SCV-enhedens umiddelbare funktioner og langsigtede strategiske betydning for spillet.

Spillerens læring af forbindelsen mellem Command Centeret og SCVenheden kan forbindes med Batesons nullæring, når den bliver anskuet som et allerede etableret kausalt forhold, der bliver gentaget uden korrektion af fejl. Denne forståelse af nullæring optræder først efter spilleren har forstået og fortsat gentager forbindelsen mellem Command Center og SCV-enhederne. Herefter vil sammenhængen mellem Command Centeret og SCV-enheden træde i baggrunden. Bevægelse fra forgrund til baggrund udtrykker i denne forståelse af nullæring et vellykket resultat af fejlkorrektion.

Denne måde at forstå nullæring på stemmer overens med Micheal Polanyis beskrivelse af tacit knowing $(1983,1992)$, som beskriver det forhold, at

"one can know more than one can tell."

(Polanyi 1983, 4).

Dette særligt, når spilleren har "glemt", hvordan et givent forhold er blevet lært og siden repeterer det uden overvejelse. Dette forhold peger tilbage på distinktionen fra indledningen om forskellen mellem at kunne forklare sin viden og kunne handle den. Eksempelvis er det som de fleste ved vanskeligt at forklare, hvordan man cykler selvom man udmærket godt kan cykle.

Nullæring kan altså betragtes som fravær af fejlkorrektion og som etableret gentagelse af vellykket læring. Disse to former for nullæring kan klassificeres som henholdsvis nullæring a og b (se figur 1) og for begge gælder det, at de ikke undersøger sig selv. 


\section{Nullæring}

Nullæring a

- fravær af fejlkorrektion-
Nullæring $b$

- etableret gentagelse af

vellykket fejlkorrektion

(tacit knowing/"usynlig")

Figur 1. Nullæring a anskuet som fravær af fejlkorrektion og nullæring b forstået som etableret gentagelse af vellykket fejlkorrektion.

\section{Batesons læringskategori 1}

Læring 1 adskiller sig fra nullæring ved at indeholde forandring. Bateson beskriver læring 1 som

\footnotetext{
"de tilfælde, hvor en entitet på tidspunkt 2 reagerer anderledes, end den gjorde på tidspunkt 1."
}

(Bateson 2005, 289)

Herved adresserer Bateson det forhold, der indtræder, når spilleren i StarCraft 2 lærer Command Centerets betydning for ressourceindsamling og som producent af SCV-enheder.

Det centrale ved læring 1 er, at den finder sted gennem "forandring i reaktionsspecificitet via korrektion af forkerte valg
inden for en mængde af alternativer." (Bateson 2005:294)

Bering Keiding og Laursen (2005) inddrager feed-back i læring 1, da "valg af handling, konstruktion af feed-back, der anvendes som
grundlag for korrektion af handling og valg af ny handling og så
fremdeles" (Bering Keiding og Laursen 2005:91)

er bestemmende for læring 1 . 
I StarCraft 2 lærer spilleren Command Centerets betydning og dets forbindelse med SCV-enheden at kende gennem feed-back som grundlag for korrektion af handling. Koblingen mellem Command Centeret betydning og SCV-enhedens muligheder bliver herefter vævet sammen til en "helhed".

Overordnet set handler læring $1 \mathrm{om}$ at forstå og forbinde forskellige enheder med hinanden. Når disse forbindelser ikke længere udsættes for fejlkorrektion træder de i baggrunden og bliver "usynlige". Denne proces forandre læring 1 til nullæring b som illustreret i figur 1 .

\section{Kontekst og kontekstmarkører i Batesons læringsteori}

Særligt relevant for inddragelsen af computerspil i forbindelse med Batesons læringsteori er hans krav om gentagelige kontekster. StarCraft 2 præsenterer gentagelige kontekster. Forbindelsen mellem læring 1 og konteksten forklarer Bateson sådan,

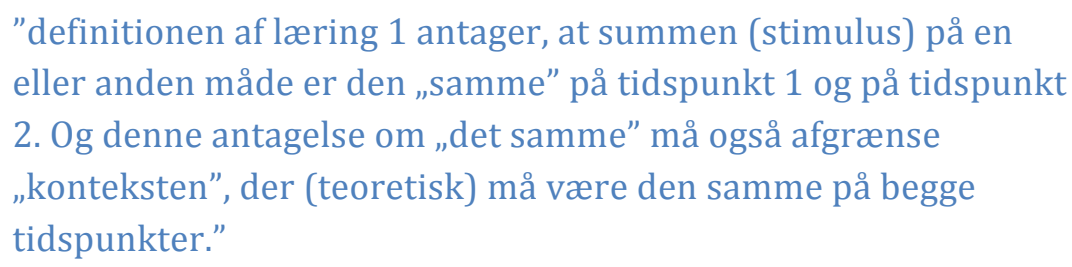

(Bateson 2005:289-290)

StarCraft 2 s kontekst, her forstået som spilsystemet, ændrer sig ikke i løbet af spillet.

Batesons definerer kontekst

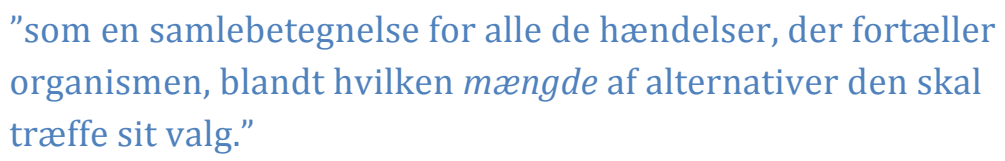

(Bateson 2005:291)

Citatets formulering af "mængde af alternativer" stemmer overens med spillerens valgmuligheder i StarCraft 2. Her konstituerer "mængden af alternativer" valg mellem enten at producere SCV-enheder i Command 
Centeret eller lade være. Eller måske mere præcist hvor mange SCVenheder spilleren vælger at producere.

Samlet set betyder det, at konteksten både skal være den samme og gentagelig og udgøre en "mængde af alternativer", hvorfra spilleren skal træffe valg. Kontekst består altså af to niveauer som vi kan kalde for- og baggrund. I StarCraft 2 er baggrunden spilsystemet, mens forgrunden er den præsenterede "mængde af alternativer", hvorudfra spilleren træffer sine valg (se figur 2).

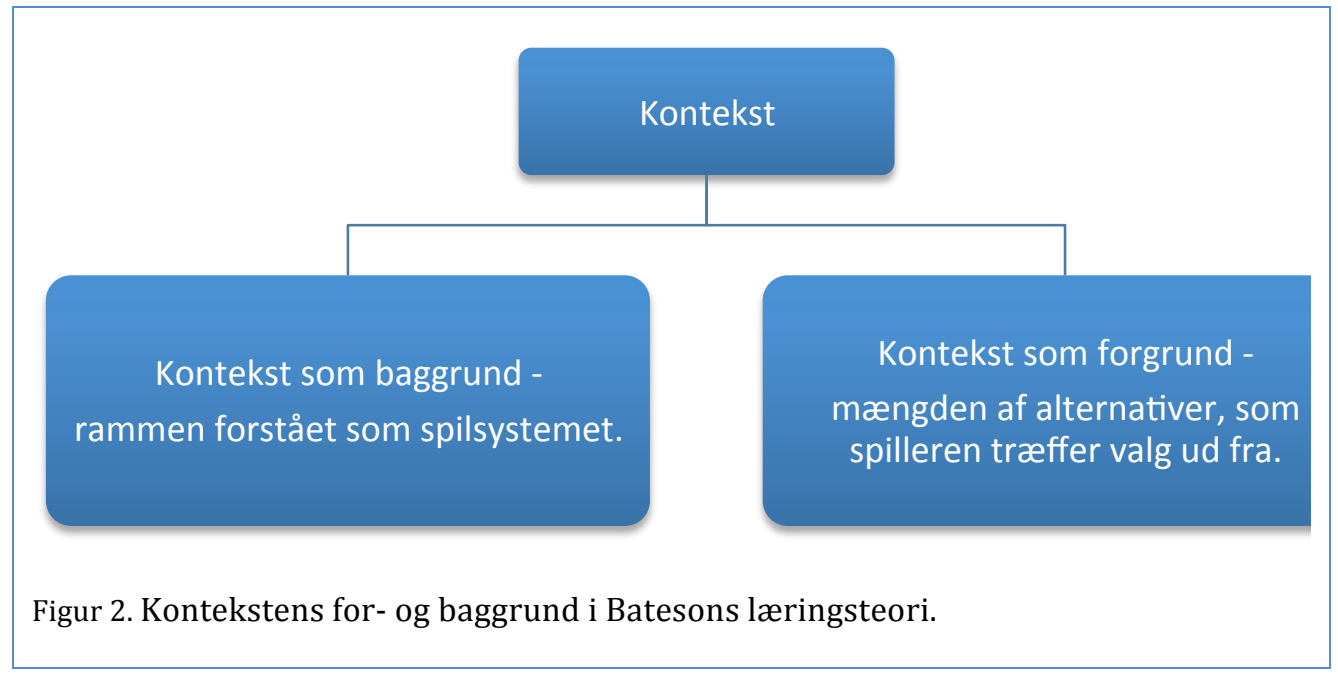

Bateson kunne nøjes med at fastholde disse to kontekstbetragtninger i sin læringsteori. Det gør han ikke. Han indfører begrebet kontekstmarkører. Disse præciserer sammenkoblede alternativer, der i givne situationer kan eller bør iværksættes. Selv eksemplificerer Bateson kontekstmarkører sådan,

\footnotetext{
"i menneskelivet og sandsynligvis også i mange andre organismers liv er der afgjort signaler, hvis hovedfunktion er at klassificere kontekster. Når selen lægges på hunden, der har fået langvarig træning i det psykologiske laboratorium, er det ikke urimeligt at antage, at den så ved, at den nu skal i gang med en række kontekster af en bestemt slags. En sådan informationskilde vil vi kalde en „kontekstmarkør”.”
}

(Bateson 2005:291) 
Kontekstmarkører er altså informationskilder, der "åbner" for en række kontekster i partikulære situationer.

I StarCraft 2 optræder kontekstmarkører enten før eller inde i missioner. Når kontekstmarkører optræder før er det som regel i forbindelse med missionsbeskrivelsen. Her finder spilleren ud af om missionen indeholder den sædvandlig basekonstruktion eller ej. Hvis kontekstmarkøren optræder inde i selve missionen kan det eksempelvis være, når der fra missionens begyndelse ikke optræder et Command Center. Det fraværende Command Center "fortæller" spilleren, at antallet af spilenheder er fastlagt på forhånd (i den slags missioner sker det sommetider, at spilleren falder over et Command Center, som spilleren så skal anvende til at fuldføre den resterende del af missionen). Dette eksemplificerer, hvordan læring 1 og kontekstmarkører er forbundet i StarCraft 2. Hvilket også betyder, at kontekstmarkører er medbestemmende for hvilke forbindelser mellem enheder (Command Center og SCV-enheder) i handlingskæder, der skal iværksættes. Eksempelvis indikerer kontekstmarkøren "opbyg base", at handlingskæden, hvor valg fra "mængden af alternativer", skal udfoldes i forhold til den partikulære mission. Kontekstmarkøren "opbyg base" indikerer således, at følgende handlingskæde bør iværksættes: anvend Command Centeret til at producere SCV-enheder og indsaml ressourcer (mineraler). Herefter kører SCV-enheden mellem Command Centeret og mineraler og indsamler ressourcer indtil, der er ressourcer nok til at producere yderligere SCV-enheder. Denne handlingskæde gentages indtil spilleren vurderer, at der tilstrækkelige SCV-enheder såvel som ressourcer til at bygge en ny bygning - et Refinery. Denne bygning muligøre indsamling af spillets anden ressource - vespene gas. Herefter er handlingskæden for spillets grundlæggende konstruktion- og ressourceindsamlingssystem etableret.

Command Center, SCV-enhed og Refinery kan herefter siges at indgå i identitetsfællesskab med hinanden, som udgør det grundlæggende konstruktion- og ressourceindsamlingssystem i StarCraft 2 . Identitetsfællesskabet minder om Martin Heideggers (1988, 2005, Dreyfus 1991) beskrivelse af brugstøjshelet. Ligesom pen, blækhus, papir, bord og 
stol udgør Command Center, SCV-enhed og Refinery et brugstøjshele. Se figur 3.

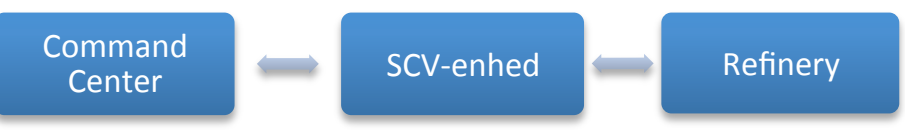

Figur 3. Illustration af læring 1 i StarCraft 2, hvor tre enheder forbindes i en handlingskæde, der hviler på et identitetsfællesskab (brugtøjshele).

Etableringen identitetsfællesskaber bliver, som allerede beskrevet, skabt gennem fejl og korrektion af disse via valg baseret på feed-back ud fra mængden af alternativer $i$ en gentagelig kontekst. Når disse handlingskæder er blevet etableret ud fra identitetsfælleskaber, kan de træde i baggrunden som automatiserede reaktioner på partikulære stimuli og/eller kontekstmarkører. Når de træder i baggrunden bliver de nullæring b (gentagelse baseret på succesfuld fejlkorrektion). Inden da er handlingskæderne i gang med at blive automatiserede.

Overgangen fra i gang med til at blive til automatiseret reaktion beskriver Claus Otto Scharmers (2001) som "not-yet-embodied knowledge" (139). I StarCraft 2 befinder spilleren sig i denne overgang, når læringen bevæger sig fra læring 1 (eksplicit viden) til nullæring b (tacit knowing). Det sidste beskriver Scharmer i øvrigt som "embodied knowledge".

Inddragelsen af Scharmer i denne sammenhæng indskyder et dynamisk lag i Batesons læringsteori, der ellers fremstiller en binær læringsforståelse mellem ikke-lært og lært.

Det dynamiske lag fokuserer på læringens nutid ved at inddrage, hvordan læring bliver til mens den foregår. Scharmers læringsforståelse tydeliggøre også at Polanyis "tacit knowing" (tavs viden) kan forstås som udtryk for allerede etableret læring. Altså læring som noget, der allerede har fundet sted. Det man kunne kalde læringens datid.

Ved hjælp af Scharmers læringssyn kan spillerens fremadrettede læring ud fra fejl og korrektion af disse gennem valg betinget af feed-back ses som "not-yet-embodied knowledge", der på et senere tidspunkt kan træde i baggrunden og blive "usynlig" som "embodied knowledge" (tacit knowing). 
Når fejlkorrektionerne fra mængden af alternativer samler sig i "lukkede" handlingskæder gennem identitetsfællesskaber og efterfølgende træder i baggrunden er læringen netop forløbet fra "not-yet embodied knowledge" til "embodied knowledge". Dette forløb beskriver overgangen fra læring 1 til nullæring b. (Se figur 4.)

$$
\begin{aligned}
& \text { Igangværende læring } \\
& \text { (i gang med at blive) }
\end{aligned}
$$

Allerede etableret læring (automatiseret reaktion)

\section{Læring 1}

(not-yet-embodied

knowledge)

Nullæring b

(embodied knowledge)

Figur 4. Illustration af læring fra i gang med til at blive til automatiseret reaktion beskrevet ud fra Batesons læringsteori og Scharmers læringssyn.

\section{Batesons læringskategori 2}

Bateson definerer læring 2 sådan,

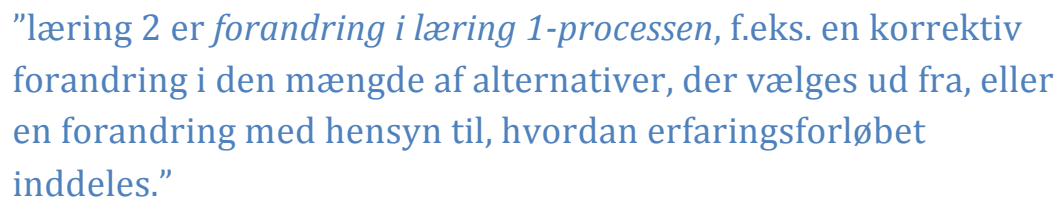

Citatet deler læring 2 op i forandringer i handlingskæden og inddelinger i erfaringsforløbet. Denne opdeling peger på, at Bateson anskuer læring 2 systemisk og erfaringsorienteret. Disse to sider er selvfølgelig tæt forbundne. Opdelingen kan illustreres på følgende vis. (Se figur 5) 


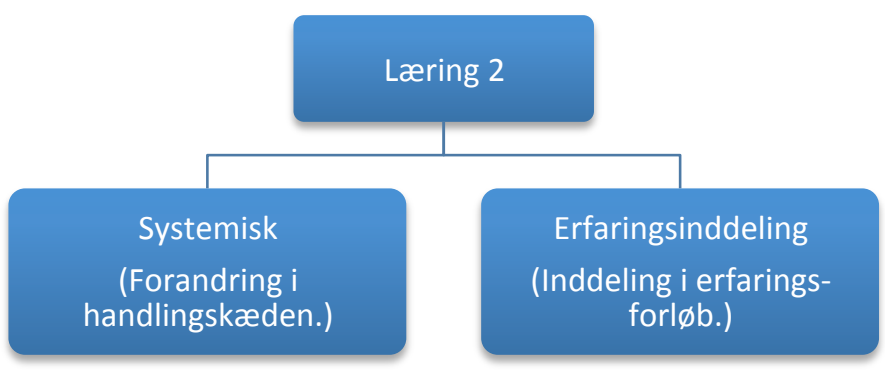

Figur 5. Læring 2 opdelt som henholdsvis systemisk og erfaringsorienteret.

I StarCraft 2 optræder systemisk læring 2 når spilleren forandre handlingskæden i identitetsfælleskabet mellem Command Center => SCVenhed => Refinery. Spilleren kan forandre handlingskæden på to måder. Den første ved at ændre antallet af elementer i handlingskæden. Denne forandring kunne se sådan ud: Command Center => 3 gange SCV-enheder => Refinery. Denne forandring indfinder sig, når spilleren erfarer, at det ikke er tilstrækkeligt at bygge én SCV-enhed før konstruktionen af Refinery. I stedet vælger spilleren nu at bygge yderligere SCV-enheder før konstruktionen af Refinery påbegyndes. Spillerens anden måde at forandre handlingskæden er ved at ændre rækkefølgen. Handlingskæden kunne nu se således ud: Command Center $=>3$ gange $\mathrm{SCV}$-enheder $=>$ Barracks (producerer soldater til angreb/forsvar) => Refinery.

Forandring i antal og rækkefølge i handlingskæden af enheder i StarCraft 2 illustrer, hvordan systemisk og erfaringsbaseret læring i læringskategori 2 er tæt forbundne.

\section{Udvidelse af forståelsen af nullæring}

Læring 2 er forbundet kontekstmarkører eller kontekster. Sammenhæng mellem læring 2, kontekstmarkører og kontekster er underlagt et ordningsprincip, der fremhæver

\footnotetext{
"forandringer i den måde, hvorpå strømmen af handlinger og oplevelser er segmenteret eller inddelt i kontekster i forbindelse med forandringer i anvendelse af kontekstmarkører."
}

(Bateson 2005: 294-295) 
I StarCraft 2 vælger spilleren at anvende forskellige handlingskæder afhængig af kontekstmarkørerne. Hvis kontekstmarkøren er "forsvar basen" anvender spileren defensive handlingskæder. Hvis kontekstmarkøren er "angrib modstander(ne)" iværksættes offensive handlingskæder.

Handlingskæder forbundet med "forsvar basen" eller "angrib modstander(ne)" virker bedst, hvis de er tilstrækkeligt indøvede. Hvis handlingskæderne enten iværksættes for langsomt eller er fejlbehæftede, så taber spilleren spillet. Herefter indlæser spilleren missionen igen og forsøger nok en gang. Men for at overleve må spilleren ændre i handlingskæderne.

Forandringer af handlingskæderne betyder, at spilleren har overvejet, hvordan enhederne skal forbindes til hinanden for at sikre et vellykket udfald. I StarCraft 2 handler læring 1 om sammensætning af enheder i handlingskæder, mens læring 2 adresserer forandringer i etablerede handlingskæder fra læring 1.

Samlet set betyder dette, at læring 1 ordner sammensætningen af enheder i rækkefølger, mens læring 2 adresserer indøvning af rækkefølgerne i handlingskæderne og forandring af ordningen af handlingskæderne. Denne læsning af Batesons læring 2 fører til to forskellige læringsniveauer indenfor samme læringskategori sådan som Yrjö Engeström (1986) også har gjort opmærksom på. Det første læringsniveau af læring 2 kan sidestilles med udenadslære. I StarCraft 2 betyder dette læringsniveau, at spilleren bliver hurtigere og hurtigere til at eksekvere fastlagte handlingskæder. Ifølge Engeström handler dette læringsniveau om repetition og reproduktion af læring 1. Repetition og reproduktion udtrykker en passiv dimension af læring 2. Dette niveau kalder Engeström læring 2a.

I computerspilforskningen er repetition og reproduktion langt fra et ukendt fænomen. Raph Koster (2004) anser repetition som grundlaget for sikker reproduktion af handlingskæder. I Theory of Fun for Game Design (2004) kalder Koster repetition for "grokking", som henviser til graden af, hvor trænet spilleren er til at eksekvere reproduktiv adfærd. "Grokking" 
beskriver det punkt, hvor spilleren ikke længere tænker over sine handlinger. Koster beskriver "grokking" som

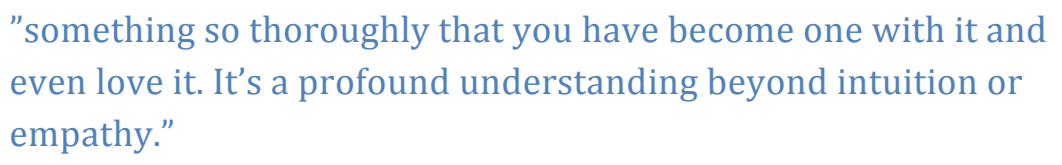

(Koster 2004:28)

Denne formulering peger på, at læring 2a ligesom læring 1 kan træde i baggrunden og blive nullæring. Herved bliver der åbnet for endnu en udvidelse af forståelsen af nullæring denne gang som resultat af læring 2a (Se figur 6.).

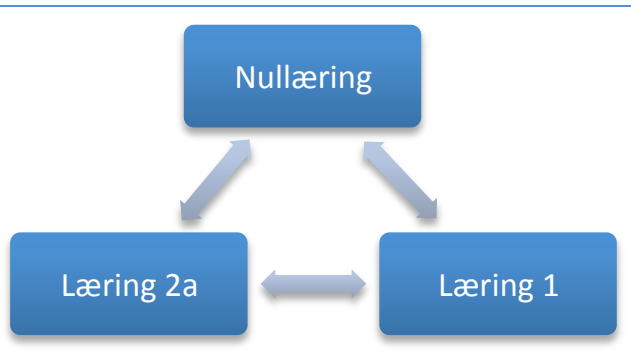

Figur 6. Illustration af, hvordan læring 1 og 2a begge kan træde i baggrunden som nullæring.

Således tegner der sig et billede af, at nullæring kan foregå på tre forskellige måder. Den første er fravær af fejlkorrektion (oprindelig nullæring). Den anden som etableret gentagelse af vellykket fejlkorrektion (læring 1). Den tredje som resultat af "grokking" eller repetition og reproduktion af den vellykkede fejlkorrektion (læring 2a). 
Dette betyder at Batesons oprindelig bestemmelse af nullæring nu kan inddeles i tre forskellige niveauer. Den første er Batesons oprindelig bestemmelse af nullæring som fraværd af fejlkorrektion. Det der tidligere i denne artikel blev kaldt nullæring a (oprindelig nullæring). Det andet nullæringsniveau der tidligere blev kaldt nullæring b (fra læring 1). Det tredje nullæringsniveau som resultat af repetition eller "grokking" kan kaldes nullæring c (fra læring 2a) (Se figur 7).

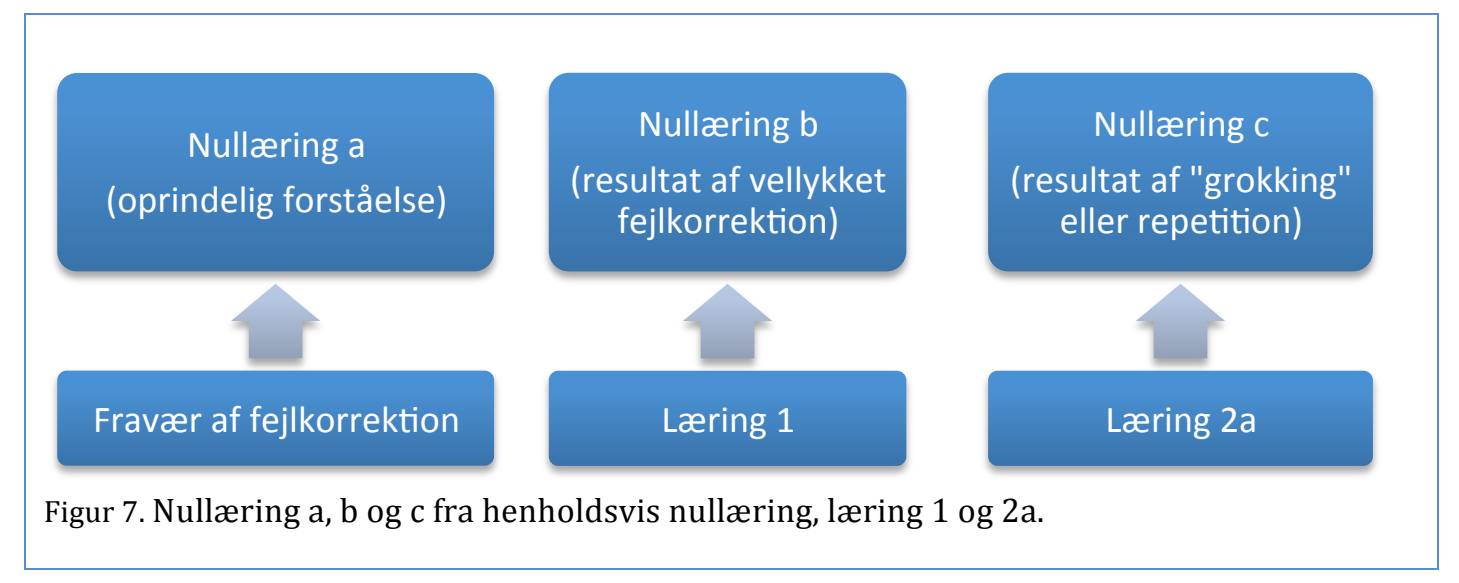

\section{Læring $2 \mathrm{a}$ og $\mathrm{b}$ forklaret og uddybet}

Engeström (1986) beskriver forskellene mellem læring 2a og b sådan:

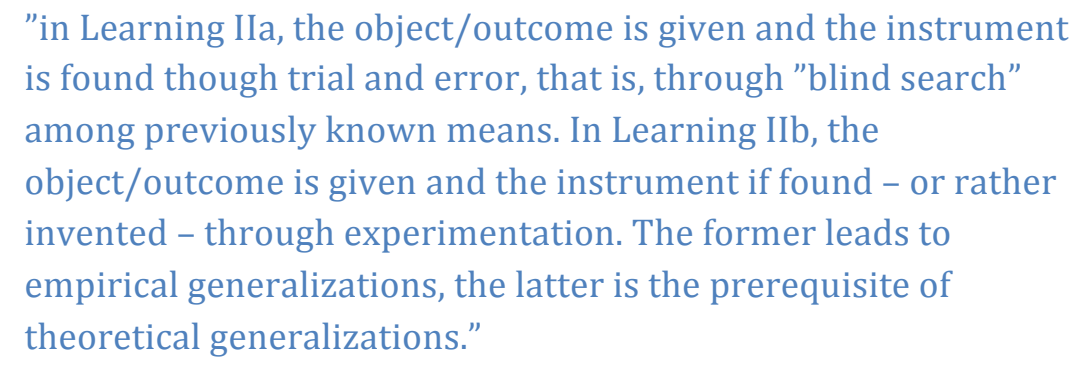

(Engeström 1986:28)

I StarCraft 2 optræder læring $2 b$, når spilleren gennem eksperimenter opdager nye strategier udhævet fra spilsystemets formelle enheder og funktionalitet (Crawford, 1982).

Samlet set gælder det for læring 2a og b, at læring 2a henviser til repetition og reproduktion af handlingskæder funderet på læring 1, mens 
gentænkning, omskabelse, rekombinering og opdagelse af nye handlingskæder henfører under læring $2 \mathrm{~b}$.

I StarCraft 2 oscillerer læring mellem 1) forståelse af enheders betydning og deres gensidige forbindelser (læring 1),2) repetition og reproduktion af handlingskæder (læring 2a), og endelig 3) eksperimenterende omdannelser af handlingskæderne (læring 2b). Og læring 1 og 2a kan, som beskrevet ovenfor, falde tilbage, blive "usynlige" og i processen omdannes til henholdsvis nullæring b og c (automatiserede reaktioner).

Læring i hver enkelt spilsession i StarCraft 2 oscillerer vertikalt mellem nullæring b og c, læring 1 og læring 2a og b. Forståelsen af læring 2 bliver udvidet, når man betragter spillerens engagement ud over den enkelte spilsession. Her medregnes læring i StarCraft 2, når spilleren er væk fra skærmen og tænker tilbage på enkelte spilsessioners udfordringer og efter spilleren er holdt op med at spille spillet. For at indfange denne læring er det frugtbart at inddrage Donald Schöns læringsforståelse fra Den reflekterende Praktiker (2007). Særlig oplagt er det at anvende Schöns reflection-in/on-action (refleksion-i/over-handling) opdelinger.

Refleksion-i-handling handler om, hvordan professionelle tænker, handler og lærer i deres praksis. Hvordan overvejelser finder sted inde i forløb eller sådan som Schaffer (2006) formulerer det i følgende citat,

\section{"reflection-in-action is the ability to think and work simultaneously - or to be more precise, to reflect on what you're doing without pausing to do it."}

(Schaffer, 2006:96).

Denne form for tænkning finder i høj grad sted i StarCraft 2.

Refleksion-i-handling stemmer overens med læring 2b, når spilleren gentænker, omformer og eksekverer forandrede handlingskæder i spilsessioner. Refleksion-i-handling beskriver med andre ord spillerens læring mens spillet er i gang.

Men omdannelse af handlingskæder ikke begrænset til at finde sted i spilsessioner. Den kan også foregå udenfor eller rettere efter spilsessioner. Dette når spilleren udenfor StarCraft 2 tænker tilbage på udfordringerne inde i spillet og overvejer, hvordan disse kan imødegås. 
Refleksion-i-handling er herved ikke afgrænset til spilsessionen. Selv forklarer Schön, at refleksion-i-handling kan strække sig over et længere forløb.

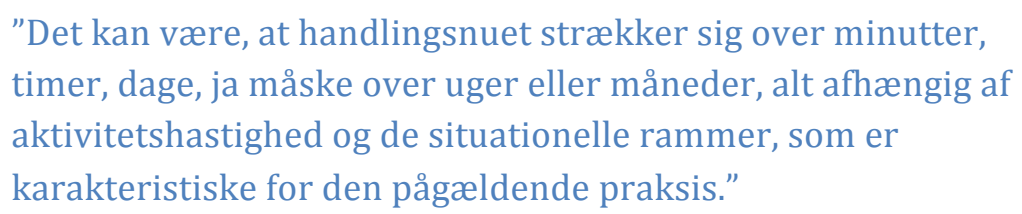

"Det kan være, at handlingsnuet strækker sig over minutter, timer, dage, ja måske over uger eller måneder, alt afhængig af aktivitetshastighed og de situationelle rammer, som er karakteristiske for den pågældende praksis."

(Schön 2007:61-62).

Denne beskrivelse af refleksion-i-handling åbner for en inddeling i to niveauer i forhold til StarCraft 2. Det første niveau handler om tænkning i spilsessionen. Dette niveau har jeg valgt at døbe situationel refleksion-ihandling.

Det andet niveau karakteriserer spillerens læring i løbet af et længerevarende spilengagement. Dette niveau er det oplagt at kalde episodisk refleksion-i-handling.

Pointen er, at det nu er muligt at tilføje en udvidelse af Engeströms udvidelse af Batesons læring 2. $\mathrm{Nu}$ omfatter læring $2 \mathrm{~b}$ læring $\mathrm{i}$ spilsessionen og efter dennes ophør, hvor spilleren væk fra skærmen overvejer ændringer i handlingskæder. Således hjælper Schöns refleksioni-handling til at opdele læringen i spilsessionen (situationel refleksion-ihandling) fra læringen under et længerevarende spilengagement (episodisk refleksion-i-handling).

Den situationelle refleksion-i-handling i er parallel med Engeströms læring 2b, mens den episodiske refleksion-i-handling åbner for en udvidelse af læring 2. Denne kan fordel kaldes læring 2c. Nu er det muligt at sondre mellem den læring, der finder sted i spilsessioner (læring $2 b$, situationel) og den, der henviser til læring efter eller væk fra skærmen (læring 2c, episodisk) under et længerevarende spilengagement.

\section{Læring 2c som afsæt for endnu en udvidelse af læring 2}

Læring 2c eller episodisk refleksion-i-handling tager som sagt udgangspunkt $i$ et længerevarende spilengagement. Denne læring kan 
videre opdeles i en individuel og kollektiv dimension. I den individuelle reflekterer (Hermansen, 1996) spilleren over spillets udfordringer, mens den kollektive optræder, når refleksionen finder sted med ligesindede. Sådanne refleksive læringsmiljøer kalder James Paul Gee (2003) affinity groups. De er kendetegnet ved, at ligesindede er orienteret mod en fælles bestræbelse. Affinity groups er som Gee skriver,

"organized around a whole process (involving multiple but integrated functions), not single, discrete, or decontextualized tasks."

(Gee, 2003:192)

Og hvert medlem af

\begin{abstract}
"the affinity group have extensive knowledge [...] By "extensive" I mean that members must be [...] able to reflect on the endeavor as a whole system, not just their part in it."
\end{abstract}

(Gee, 2003:192)

Viden i disse affinity groups er overvejende
"tacit (embodied in members' mental, social and physical coordination with other members and with various tools, and technologies)."

(Gee, 2003:193)

Citaterne beskriver, hvordan individer kollektivt reflekterer over fælles udfordringer. Heri indgår de enkelte medlemmers overvejelser som dele i en samlet og spredt refleksion, der vedgår alle aspekter af et partikulært computerspil her StarCraft 2.

Herved har Gee ikke kun beskrevet et refleksivt fællesskab, men også indfanget forbindelseslinjerne mellem den enkelte spilleres episodiske refleksion-i-handling (læring 2c) med en social enhed. Tilsammen udgør individerne $\mathrm{i}$ en affinity group et refleksivt praktikum. Herved kan man sige, at affinity groups forbinder den enkelte spillers episodiske refleksioni-handling (læring 2c) med en kollektiv dimension af selvsamme læring. 


\section{Sidste udvidelse af læring 2}

Denne sidste udvidelse af læring 2 har som skrevet afsæt i Schöns reflection-on-action (refleksion-over-handling), der handler om overvejelser efter et afsluttet forløb. Schaffer forklarer, at refleksion-overhandling er,

"when one looks back on a completed task or process to consider the implications and consequences of actions."

(Schaffer 2006:96).

Den evaluerende position reflekterer efter afslutning altså tilbage på et længerevarende spilengagement. Refleksion-over-handling indeholder således både den situationelle såvel som den episodiske læring. Denne læring er det oplagt at kalde for læring $2 \mathrm{~d}$ (evaluerende/refleksion-overhandling). En samlet opstilling over alle udvidelserne af læring 2 kan ses i nedenstående figur 8.

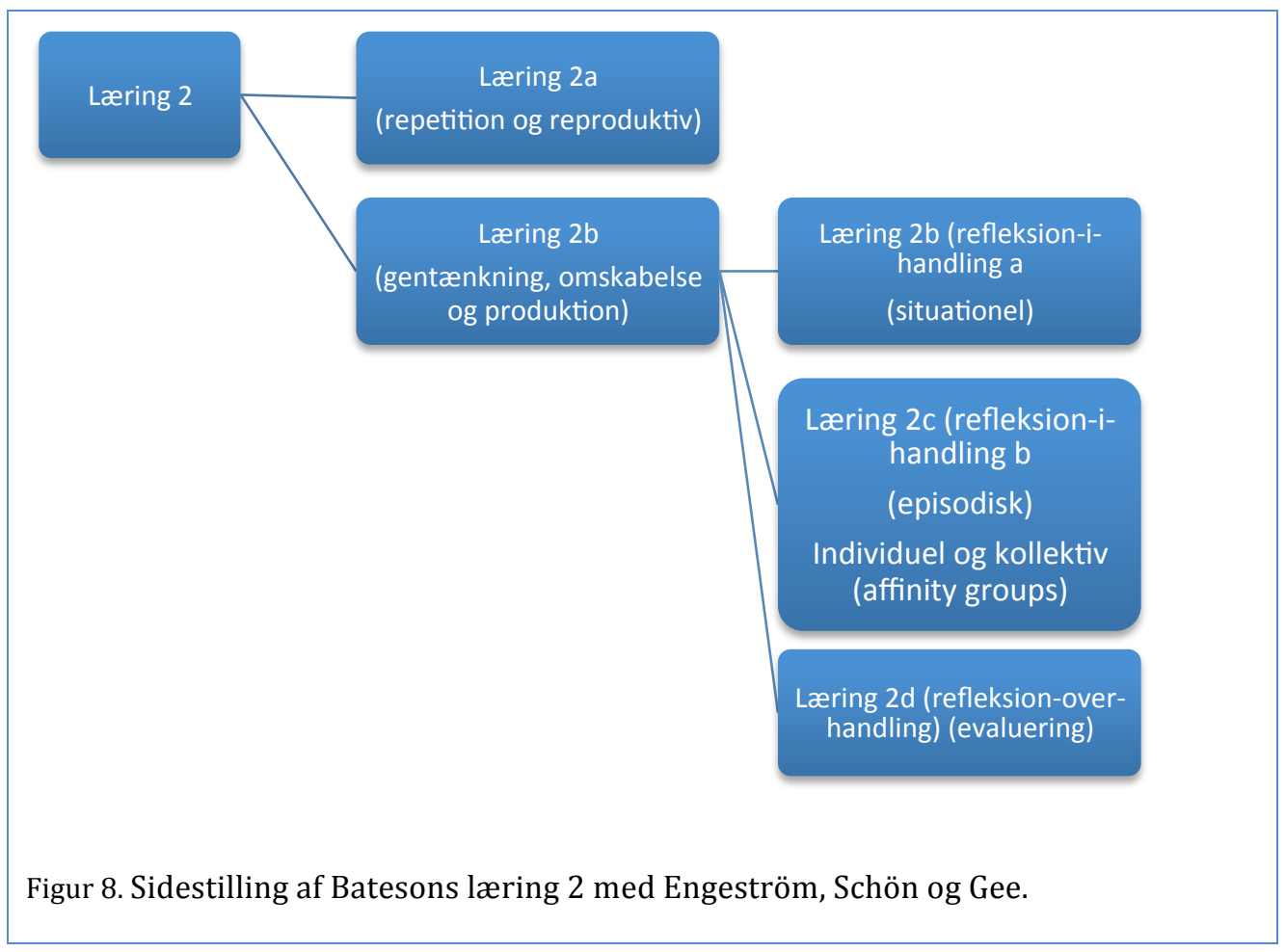


Herved er gennemgangen af læring 2 afsluttet, hvilket betyder, at udpakningen af Batesons læringsteori i forhold til StarCraft 2 er nået frem til næste og sidste læringsniveau nemlig læring 3.

\section{Batesons læring 3}

Om læring 3 skriver Bateson, at den

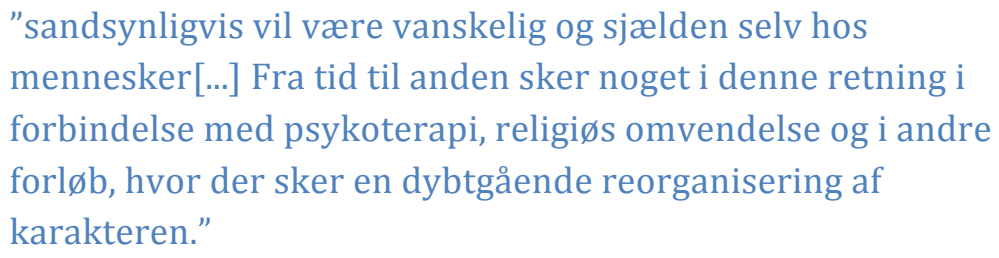

Formuleringen "dybtgående reorganisering af karakteren" peger på grundlæggende forandring, der rækker ud over læring 1 og 2 .

Læring 1 og 2a, b, c, og d adresserer som klargjort organisering inden for gentagelig kontekst ud fra mængden af alternativer, mens læring 3 handler om ændringer i selve konteksten(er).

Bering Keiding og Laursen forklarer, at læring 3 skal

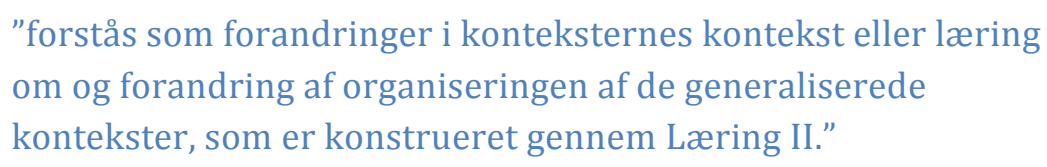

Bateson peger selv på, at sådan en reorganisering kan være farlig. Hvorfor det lader til, at personer bør "forsøge" at "undgå" læring 3 og fortsat blive i spændingerne fra læring 2. Disse spændinger refererer Bateson til som dobbelt-bind. Og Engeström minder os om disses betydning for læring 3, når han skriver, at

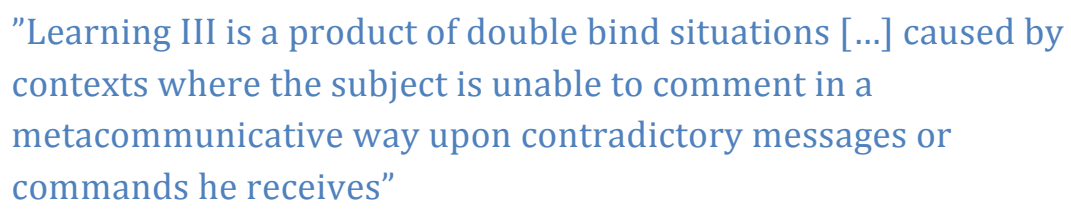

(Engeström 1986:29) 
Her læser Engeström Batesons artikel Mod en teori om skizofreni fra Mentale Systemers Økologi (2005) ind i sin forståelse af læring 3.

I denne artikel beskriver Bateson, hvordan Zenlæren forsøger at fremkalde oplysning hos sin elev ved at udsætte denne for dobbelt-bind.

”En af de ting, han [Zenlæren] gør, er at holde en stok over
elevens hoved og med skarp stemme sige: „Hvis du siger, at
denne stok er virkelig, slår jeg dig med den. Hvis du siger, at
denne stok ikke er virkelig, slår jeg dig med den. Hvis du ikke
siger noget, slår jeg dig med den [...] Zeneleven kan rejse sig og
tage stokken fra læreren - som måske ville acceptere dette svar.”

(Bateson 2005:219)

Citatet eksemplificerer læring 3 som reorganisering af betingelserne for læring: eleven tager staven fra Zenlæren og ændre konteksten for læring. Læring 3 er

"særdeles krævende og måske omkostningsfyldt læring."

(Bering Keiding og Laursen 2005:104)

Endda så meget, at de pågældende forfatterne ikke mener,

"at Læring III bør tilstræbes i nogen form for uddannelses- eller undervisningsforløb."

(Bering Keiding og Laursen 2005:104)

I forbindelse med StarCraft 2 kan læring 3 beskrives som den hændelse, der indfinder sig, når et krydspres mellem spillets og omgivelsernes krav kræver en dybtgående forandring i forholdet til selve spillet. Sådan at spilleren må gøre ligesom zeneleven og opløse dobbeltbind-situationen ved at træde enten længere ind i spillet (måske blive professionel spiller) eller ud af spillets påvirkning (fravriste sig dets greb over spilleren).

Engeström uddyber krydspresset på spilleren sådan:

"double bind may now be reformulated as a social, societally essential dilemma which cannot be resolved through separate 
individual actions alone - but in which joint cooperative actions can push into emergence a historically new form of activity."

(Engeström 1986:34)

Forløsning af spændingerne i dilemmaet opstår ikke som følge af refleksion, men derimod, som Bering Keiding og Laursen peger på, som resultat af en læreproces, der udtrykker sig

"som værende af dybt rodfæstet, ikke-bevidst og ikke-sproglig karakter."

\section{(Bering Keiding og Laursen 2005:103)}

Dette præciserer samtidigt hvorfor også Bateson mener, at læring 3 ikke skal omgås med lethed.

Herved er den udvidede gennemgang af Batesons logiske læringskategorier afsluttet. Nu skal blikket rettes mod, hvad der skaber forandring i overgangene mellem læringskategorierne.

\section{Forskel og identitet}

Batesons logiske læringskategorier handler nok om forandring som målestok for overgangene mellem dem, men den undersøger ikke, hvad der afgør, at et element bliver genstand for læring og andet ikke gør det. Dette forhold undersøger Bateson derimod i artiklen Form, Substans og Forskel også fra Mentale Systemers Økologi (2005). Her tager Bateson udgangspunkt i Korzypskis dyade mellem territoriet og kortet. Denne behandler relationen mellem generalisering og partikularitet, abstrakt og konkret eller kontekst og indhold.

Korzypski dyade er handler altså om, hvad der udvælges fra territoriet og kommer med på kortet. Bateson betragter Korzypskis dyade som analogi til læringens selektion. Ligesom dyaden udtrykker, hvad der bliver udvalgt fra territoriet og medtaget på kortet, så udtrykker læring en selektion (udvælgelse) af, hvad der bliver valgt ud fra mængden af alternativer. Herfra opstår følgende og afgørende spørgsmål om, hvad det så er, der afgør selektionen?

Bateson svarer sådan, 


\begin{abstract}
"hvis territoriet nu var ensartet, ville der ikke komme andet på kortet end dets grænser, som er de steder, hvor det holder op med at være ensartet i forhold til en større matrix. Det, der kommer på kortet, er i virkeligheden forskel, det være sig en forskel i højde, en forskel i vegetation, en forskel i befolkningsstruktur, forskel i overflade, eller hvad det nu kan være. Forskelle er de ting, der kommer på et kort.”
\end{abstract}

(Bateson 2005:444).

Herved beskriver Bateson forskel som selektionsprincip for, hvad der kommer med på kortet. Forskel bestemmer derfor også hvad der bliver genstand for læring. I StarCraft 2 træder Command Centeret frem som forskel fra terrænet og udgør derved den forskel, som determinerer, at det bliver valgt.

Herved kunne det siges, at svaret på, hvad der bestemmer forandring og derved læring, er besvaret. Dette er kun delvist rigtigt, da selve forskelsforståelsen står ubehandlet tilbage. En forskel i sig selv hverken beskriver eller forklarer, hvad en forskel er. Bateson er selv inde på, at besvarelsen måske ikke er helt lige til. Eksempelvis spørger han dunkelt,

\title{
"hvad er en forskel? En forskel er et meget mærkværdigt og uklart begreb."
}

\section{(Bateson 2005:444)}

Herefter forsøger Bateson sig med, at en forskel hverken er en ting eller en hændelse. Selv skriver han, at der er forskel på forskelle og at de så at sige bør klassificeres. I Jaques Derridas $(1982,2005)$ differance-filosofi som har forskel som omdrejningspunkt bliver forskel bestemt som hverken en genstand, fænomen i ontologisk forstand ej heller ord eller begreb i epistemologisk henseende. Selv skriver Derrida, at forskel hverken har "eksistens eller essens." (Derrida 2005:51) Følgende må han opfinde et nyt ord for forskel - differance. I Derridas forståelse er forskel på en gang betinget af og bestemmende for temporalitet og spatialitet. Forskel udfolder sig i tid parallelt med, at der opstår afstand mellem nær og fjern. Herfra følger, at forskel ikke "kun" udgør en temporal, men også en spatial deling mellem fravær og nærvær gennem spredning af rum. 
Følgende forskellen indfinder der sig et spor. Dette spor udgør fravær af nærvær, fordi nærvær altid er umuliggjort af tidens gang. I Døden og Maskinen (1981) forklarer Peter Kemp sporet sådan, når han skriver,

"eftersom intet kan unddrage sig tiden, er intet rent nærværende, men alt er altid allerede fortid og findes kun som et spor."

(Kemp 1981:94)

Forskel hos Derrida lader til at være både mulighed og betingelse for alt andet.

Bateson inddrager iagttagelsen (udvælgelse) for at forstå forskel. Dette når han skriver,

"i Kritikken af dømmekraften hævder Kant - hvis jeg forstår ham ret - at den mest elementære æstetiske handling er udvælgelsen af en kendsgerning. Han viser, at der i et stykke kridt er et uendeligt antal potentielle kendsgerninger."

(Bateson 2005:445)

Bateson modificerer Kant sådan,

"at der findes et uendeligt antal forskelle i og omkring

kridtstykket."

(Bateson 2005:445)

Med til kridtstykkets forskelle skal dets potentielle placeringer medregnes, sådan at der nu optræder et

"uendeligt antal forskelle mellem dets [kridtets] placering og alle de steder, hvor det kunne have været. Af denne uendelighed udvælger vi et meget begrænset antal, der bliver til information. Det, vi forstår ved information - den elementære informationsenhed - er i virkeligheden en forskel, der gør en forskel."

(Bateson 2005:445) 
Citaterne lægger op til to niveauer i forståelsen af forskel hos Bateson. Det første adresserer kontrasten mellem et iagttagelsespunkt og en genstand (kridtstykket), mens det andet er er forbundet med iagttagerens udvælgelse. Herved er forskel dels betinget af relationen mellem iagttagelse og genstand og dels afhængig af et valg. Samlet set kan disse to niveauer beskrives som forskellens for- og baggrund. I praksis er de selvfølgelig uadskillelige.

Derrida og Batesons forskelsforståelse berører begge det forhold, at forskel aldrig kan stå alene. Dette hvad enten forskel følges af et spor eller udgør den forskel, som gør en forskel. Hos Derrida er forskelshandlingen sporsættende, mens den hos Bateson filtrerer relationen mellem bag- og forgrund. Indbygget heri er, at forskel ikke kan være forskel uden identitet. Identitet skal i denne sammenhæng forstås som resultat af forbindelseslinjer eller slægtsskaber mellem det, som forskellen er del af gennem sin forskel.

Det lader til, at Bateson overser betydningen af identitet mellem enten forskel som forskel fra (for-baggrund) eller når forskel forbinder sig til en anden forskel gennem ensartethed (identitet/valg).

Korzypskis dyade illustrerer dette ganske enkelt i og med, at bjerget som forskel nok træder frem på kortet, men denne fremtræden er kun mulig på baggrund af, at bjerget er forskelligt fra det andet på kortet og at bjerget forbinder sig til andre bjerge (ensartet). Herved træder bjerget frem som forskel fra og som forbindelseslinje til andre forskelle (andre bjerge). Forskel er med andre ord mulig, fordi forskellige (bjerge) er forskellige på ensartet vis (identitet) og at disse står i kontrast til ikke-bjerge (baggrund). Og da bjerge er beslægtede med hinanden, så optræder de i et identitetsfælleskab. Forskel er ikke kun forskel ud fra sig selv, men også gennem forbindelse med andre forskelle.

I StarCraft 2 er Command Centeret som allerede nævnt en forskel i og med at det er forskelligt fra terrænet, men det er samtidig indskrevet i et identitetsfælleskab med alle andre bygninger i spillet.

Således kan dette afsnit afrundes ved at pege på, at forskelle gør en forskel, når de er forbundet med hinanden i identitetsfællesskaber. Hvis forskelle ikke er forbundet med hinanden, så optræder de uden 
sammenhæng eller kontekst, hvilket sikkert vanskeliggøre iagttagelsen af dem som "en forskel, der gør en forskel."

Herved er grundlaget lagt for at bevæge sig videre til det teoriproducerede afsnit.

\section{Elementerne i et udkast til en ekspansiv læringsteori}

Denne artikel lagde ud med at præsentere en dobbelt ambition. Den første var at undersøge, hvordan læring foregår i StarCraft 2. Dette belyst ud fra Batesons læringsteori, der undervejs er blevet udvidet. Den anden ville fra ud fra resultatet af den første ambition præsentere et udkast til ekspansiv læringsteori, der inddrager forskel, identitet, selvreferents og ekspansion.

I StarCraft 2 ekspanderer (Engeström 2001) læringen sig i takt med stigende missionskompleksitet. Gennem konstruktion- og ressourcesystemet oplever spilleren vækst i antallet af enheder og indbyrdes relationer. Læring i StarCraft 2 ekspanderer gennem løbende forandringer.

Ekspansion er et ubehandlet fænomen i Batesons logiske læringskategorier. Dette selvom ekspansion finder sted i sammensætninger af forskelle $\mathrm{i}$ identiteter i stadig fremadskridende kompleksitet, hvor forskelle gennem overensstemmelser med hinanden skaber forbindelser, der kan gøre en forskel i kontrast til det, som identiteterne af forskelle er forskellige fra.

Indbygget i forståelsen af forskel er identitet forstået som overensstemmelse. Dette betyder, at forskel og identiteter er forbundet til selvreferents. For at identitet kan blive sammensat af forskelle, så kræver det referents mellem forskelle. Og siden forskellene er ens, så følger det, at referents mellem identiske forskelle bliver til selvreferents. Her er det væsentligt at holde sig for øje, at selvrefererende identiteter i sig selv kan danne nye forskelle til det som de ikke er identiske med.

Når forskel, identitet og selvreferents forbindes med ekspansion, så optræder forskelle på fire måder: den første måde er forskel, der gør en forskel (bjerget, der er forskelligt fra ikke-bjerge); den anden måde er forskelle som forbundne gennem identitet (det ene bjerg finder mening 
gennem referents til det andet bjerg og omvendt - gensidig referents eller selvreferents); den tredje måde handler om forskellenes baggrund (bjerge er sammen forskellige i forhold til baggrunden, der bliver udgjort af alt det som ikke er identisk med bjerge (ikke-bjerge)); den fjerde måde er forskelle sammensat i grupper af forskelle i identiteter, der gør en forskel (bjergene udgør som gruppe en forskel, der gør en forskel i forhold til andre grupper af forskelle (skove).

Herved er de grundlæggende elementer til en ekspansiv læringsteori skitseret. Det følgende udkast til en ekspansiv læringsteori vil blive belyst ud fra StarCraft 2. Eksemplificeringen af udkastet til en ekspansiv læringsteori vil også indeholde en udvidet beskrivelse af forskel, identitet, selvreferents og ekspansion.

\section{Udkast til en ekspansiv læringsteori}

I StarCraft 2 konstituerer Command Centeret som skrevet en forskel som gør en forskel. En forskel som er vanskelig at begribe før en anden forskel, som gør en forskel, nemlig SCV-enheden, bliver forbundet med den første forskel (Command Centeret). Før spilleren i tilstrækkelig grad kan begribe de to forskelle, må de forbindes med hinanden. Når de er blevet forbundet med hinanden, så refererer de forklarende til hinanden. De indgår med andre ord i et identitetsfællesskab med hinanden. Herved eksemplificerer de to enheder, hvordan to forskelle indgår $\mathrm{i}$ et selvrefererende identitetsfællesskab med hinanden.

Dette forhold mellem de to forskelle og deres identitetsfælleskab kan formelt formuleres sådan, at forskel A og forskel B træder frem som forskelle, der gør en forskel, når de bliver forbundet med hinanden i et selvrefererende identitetsfælleskab 1 (identitetsfællesskaberne altid anført med tal) på baggrund af en ramme X.

Identitetsfællesskabet 1 mellem forskelle A og B udgør samtidig den første ansats til en kontekst, hvori forskelle A og B kan begribes som ikke-identisk forgrund i forhold til baggrunden, ramme X. Kontekst og ramme er forskellige fra hinanden. I StarCraft 2 indtræder Command Centeret og SCV-enheden som forskelle, der er på vej til at lave en forståelseskontekst, hvori enhederne indgår. Dette foregår indenfor spilramme X. 
Ansats er netop en ansats og derfor ikke en færdig eller fuldstændig kontekst. Herved postuleres det, at en kontekst er formet af samlinger af forskelle forenet i identitetsfælleskaber. Kontekst ligner på den vis Heideggers brugstøjsforståelse, hvor pen, blækhus, papir, bord og stol forener sig i et sammenhørende hele eller kontekst på baggrund af en ramme, der her kan siges at være arbejdsværelset eller kontoret.

Når Command Centeret og SCV-enheden i StarCraft 2 er trådt frem som forskelle, der gør en forskel gennem identitetsfælleskab med hinanden, indfinder der sig endnu en forskel. Denne er de blå krystaller i landskabet ved siden af Command Centeret. De udgør som tidligere beskrevet ressourcer, som skal indsamles af SCV-enheden. Herved ekspanderer identitets-fælleskabet 1 mellem forskellene Command Center og SCVenhed ved at inddrage endnu en forskel, de blå krystaller (ressourcer). Inddragelsen af endnu en forskel til de to i forvejen sammenhængende forskelle peger på sammensætningens horisontale såvel som ekspansive karakter.

Formelt set kan ekspansionen beskrives sådan, at forskel A og forskel B gennem forbindelse med hinanden danner selvrefererende identitetsfælleskab 1 i ramme $\mathrm{X}$, som herefter forbinder sig med forskel C og derigennem skaber ekspansion. Ekspansionen omskriver samtidig relationen mellem forskel A, B og C til identitet 2. Denne proces kan formelt opdeles i tre forløb. Disse ser nogenlunde således ud:

1. Forskel A forefindes i ramme X.

2. Forskel A og Forskel B skaber Identitetsfællesskab 1 i ramme X. (Forbindelsen af forskel A og B skaber første ansats til kontekst Z bestående af Identitetsfællesskab 1.)

3. Identitetsfællesskab 1 (Forskel A og Forskel B) forbinder sig med Forskel C og bliver til Identitetsfællesskab 2 i ramme X og skaber anden ansats til kontekst Z (Identitetsfælleskab 1 og 2).

Læreringen slutter ikke her. Den fortsætter med at ekspandere. I StarCraft 2 lærer spilleren, at SCV-enheden udover at være ressourceindsamler også fungerer som konstruktionsenhed. SCV-enheden fungerer med andre ord ikke udelukkende til at indsamle ressourcer. 
Herved forandres den etablerede Forskel C (ressourceindsamling) sig gennem inddragelse af endnu en forskel til Forskel D (konstruktion). Herefter bygger spilleren med SCV-enheden et Refinery, som muliggør indsamling af Vespene Gas. Denne indsamling foregår også med SCVenheden, hvilket igen ekspanderer forståelsen af SCV-enheden. Der indskrives altså endnu en forskel, indsamling af vespene gas (Forskel E). Herefter forstår spilleren, at SCV-enheden er samlingspunkt for indsamling af ressourcer, mineraler såvel som vespene gas. Tilsammen udgør dette Forskel F.

Disse forskydninger af forskelle og skabelse af identitetsfælleskaber i et ekspansivt felt ser sådan ud, når de indsættes i fortsættelsen af det ovenstående forløb.

1. Identitetsfællesskab 2 (Forskel A, B og C) forbinder sig med Forskel D og bliver til Identitetsfællesskab 3 i ramme X og skaber tredje ansats til kontekst Z (Identitetsfællesskab 1, 2 og 3)

2. Identitetsfællesskab 3 (Forskel A, B, C og D) forbinder sig med Forskel E og bliver til Identitetsfællesskab 4 i ramme X og skaber fjerde ansats til kontekst Z (Identitetsfællesskab 1, 2, 3 og 4)

3. Identitetsfællesskab 4 (Forskel A, B, C, D og E) forbinder sig med forskel $\mathrm{F}$ og bliver til identitetsfællesskab 5 i ramme $\mathrm{X}$ og skaber den femte og sidste ansats til kontekst Z (Identitetsfællesskab 1, 2, $3,4 \operatorname{og} 5)$

Identitetsfællesskab 5 fuldender i StarCraft 2 kontekst Z som udgør spillerens læring af spillet grundlæggende konstruktions- og ressourcesystem.

Herved er et initialt udkast til en ekspansiv læringsteori ud fra forskel, identitet, selvreferents og ekspansion med udgangspunkt i StarCraft 2s konstruktions- og ressourcesystem blevet beskrevet.

Dette læringsteoretiske udkast tager ikke kun hensyn til elementerne: forskel, identitet, selvreferents og ekspansion, men også til deres indbyrdes horisontale og vertikale dynamikker (temporale såvel som spatiale). Udkastet beskriver en horisontal såvel som en vertikal struktur, hvori læring bliver anskueliggjort som et ekspansivt fænomen baseret på forskel, 
identitet og selvreferents. Herved skulle det også gerne fremgå, at dette læringsteoretiske udkast betoner læringens horisontale og vertikale dimensioner i modsætning til Batesons betoning af læringens vertikale dimension.

Betoningen af den ekspansive dynamik i dette læringsteoretiske udkast understreger, hvordan kontekster vokser frem gennem selvreferents mellem forskelle i identitetsfællesskaber. Denne dynamik betyder videre, at kontekster kan indgå som selvstændige forskelle med andre forskelle eller kontekster. Derigennem rummer dette læringsteoretiske udkast tilstrækkelig rummelighed til at indbefatte både stigende horisontal og vertikal kompleksitet.

Sammenfattende kan det siges, at dette ekspansive læringsteoretiske udkast er sammensat af stigningstakster i kompleksitetsniveauer. Disse kan overordnet inddeles i tre; den første er forskelle som identitetsfællesskaber; den anden er identitetsfællesskaber som selvstændige forskelle, der danner forbindelser med andre identitetsfællesskaber af forskelle; den tredje er kontekster betragtet som selvstændige forskelle, der kan danne forbindelser til andre kontekster eller identitetsfælleskaber eller forskelle.

Det skal understreges, at forbindelseslinjerne mellem forskel, identitet og kontekst ikke udtrykker en lineær læringsprogression, men derimod læring der både kan forløbe horisontalt og/eller på tværs af vertikale såvel som horisontale niveauer i og med at forskel kan inddrages i et allerede eksisterende identitetsfællesskab eller kontekst og omvendt.

Stigningstaksten i kompleksitet betyder, at dette læringsteoretiske udkast som helhed skitserer, at læring ikke enten er horisontal eller vertikal, men derimod en formation, der kan lignes med et ekspansivt rummeligt væv, der bliver til under læringen.

Analogien til et rummeligt væv understreger, at læringen skal forstås som sammensat af forbindelseslinjer mellem forskudte niveauer. Herved kunne strukturerne (matricen) i dette ekspansive læringsteoretiske udkast minde om Deleuze og Guttaris (2005) beskrivelse af rhizomet.

Herved er dette udkast til en ekspansiv læringsteori nået til vejs ende. Den ekspansive læringsteori hviler på forskel, identitet, ekspansion og 
selvreferents. Den ekspansive dimension peger på den indre dynamik mellem teoriens elementer. Ekspansionen kan foregå horisontalt såvel som vertikalt og som krydsninger mellem niveauerne. Samlet set skulle det læringsteoretiske udkast gerne understrege læring som en bevægelse, der gennem forskel, identitet, ekspansion og selvreferents efterlader et billede af et rummeligt væv, der bliver til i løbet af læringen.

StarCraft 2 har igennem hele artiklen fungereret til at eksemplificere, udvide og diskutere centrale begreber i Batesons læringsteori. Sammen har de dannet grundlag for et udkast til en ekspansiv læringsteori. Alt dette kun muligt, når det analytiske blik undersøger, hvordan læring foregår i computerspil.

\section{Referencer}

Bateson, Gregory (2005). Mentale Systemers Økologi. Akademisk Forlag.

Bogost, Ian (2007). Persuasive Games - The Expressive Power of Videogames. The MIT Press.

Deleuze, G. og Guattari, F. (2005). Tusind Plateauer - Kapitalisme og Skizofreni. Det Kongelige Danske Kunstakademis Billedkunstskoler.

Derrida, J. (1982). Margins of Philosophy.The University of Chicago Press.

Derrida, J. (2005). Difference. Det lille Forlag.

Devlin, Keith (2011). Mathematics Education for a New Era - Video Games as a Medium for Learning. A.K. Peters, Ltd.

Dreyfus, Hubert L. (1991). Being-in-the-world. A commentary on Heidegger's Being and Time, Division 1. The MIT Press. Cambridge, Massachusetts, London, England.

Engeström, Yrjö (1986). The Zone of Proximal Development as the Basic Category of Educational Psychology in The Quarterly Newsletter of the Laboratory of Comparative Human Cognition, Volume 8, Number 1 http://lchc.ucsd.edu/Histarch/ja86v8n1.PDF.

Engeström, Yrjö (2001). Expansive Learning at Work: Toward an activity theoretical reconceptualization in Journal of Education and Work. Vol 14. No 1.

Gee, James Paul (2003). What Video Games Have to Teach us about Learning and Literacy. Palgrave Macmillan.

Gee, James Paul (2005). Good Video Games and Good Learning, Phi Kappa Phi Forum. Vol. 85, No 2. 
Gleerup, Jørgen (2011). Viden (skabs) teori i Videnteori, Professionsuddannelse og Professionsforskning red. Niels Buur Hansen og Jørgen Gleerup. Syddansk Universitetsforlag.

Goetz, Thomas (2011). Harnessing the Power of Feedback Loops. Wired http://www.wired.com/2011/06/ff_feedbackloop/all/

Heidegger, Martin (2007). Væren og Tid. Klim.

Heidegger, Martin (1988). The Basic Problems of Phenomenology. Translated by Albert Hofstadter, Indiana University Press.

Hermansen, Mads (1996). Læringens Univers. Forlaget Klim.

Keiding, Tina Bering og Laursen, Erik (2005) Interaktion og læring Gregory Batesons bidrag. Forlaget UP.

Kemp, Peter (1981). Døden og Maskinen. Bibliotek Rhodos.

Koster, Raph (2004). Theory of Fun for Game Design. Paraglyph Press.

Perry, Lee (2013). The single most useful advice I can give for making any game better.. feedback. Gamasutra http://gamasutra.com/blogs/LeePerry/20130506/191739/The_single_ most_useful_advice_I_can_give_for_making_any_game_better_feedback.p hp

Polanyi, Michael (1983). The Tacit dimension. Gloucester, Mass.

Polanyi, Michael (1992). Personal Knowledge - Towards a Post-Critical Philosophy. The University of Chicago Press.

Qvortrup, Lars (2005). Det vidende Samfund - mysteriet om viden, læring og dannelse. Forlaget UP.

Scharmer, Claus Otto (2001). Self-transcending knowledge: sensing and organizing around emerging opportunities. Journal of Knowledge Mangement. Vol 5, nr. 2. pp. 137-150.

Schön, Donald A. (2007). Den Reflekterende Praktiker - Hvordan professionelle tænker, når de arbejder. Klim.

Shaffer, David Williamson (2006). How Computer Games Help Children Learn. Palgrave Macmillan.

Sicart, Miguel (2008). Defining Game Mechanics in Game Studies - the international journal of computer game research. Vol 8 issue 2 . http://gamestudies.org/0802/articles/sicart

Yee, Nick (2014). The Proteus Paradox. Yale University Press.

\section{Nævnte computerspil}

StarCraft 2 (Blizzard 2010) 
